\title{
Marie Krysinska, Poèmes choisis suivis d'Etudes critiques
}

\section{Maria Emanuela Raffi}

\section{Q OpenEdition}

1 Journals

\section{Edizione digitale}

URL: http://journals.openedition.org/studifrancesi/2242

DOI: 10.4000/studifrancesi.2242

ISSN: 2421-5856

\section{Editore}

Rosenberg \& Sellier

\section{Edizione cartacea}

Data di pubblicazione: 1 aprile 2014

Paginazione: 175

ISSN: 0039-2944

\section{Notizia bibliografica digitale}

Maria Emanuela Raffi, « Marie Krysinska, Poèmes choisis suivis d'Etudes critiques », Studi Francesi

[Online], 172 (LVIII | I) | 2014, online dal 01 avril 2014, consultato il 18 septembre 2020. URL : http:// journals.openedition.org/studifrancesi/2242 ; DOI : https://doi.org/10.4000/studifrancesi.2242

Questo documento è stato generato automaticamente il 18 settembre 2020.

\section{(c) (i) (9)}

Studi Francesi è distribuita con Licenza Creative Commons Attribuzione - Non commerciale - Non opere derivate 4.0 Internazionale. 


\title{
Marie Krysinska, Poèmes choisis suivis d'Etudes critiques
}

\author{
Maria Emanuela Raffi
}

\section{NOTIZIA}

MARIE KRYSINSKA, Poèmes choisis suivis d'Etudes critiques, choix, présentation et notes de SETH WHIDDEN, Université de Saint-Etienne, 2013, pp. 309.

1 Poetessa di origine polacca, con una cultura musicale formata a Parigi, Marie Krysinska appare nella presentazione di Seth Whidden come la sola poetessa della fine dell'Ottocento entrata, sia pure in un modo un po' particolare, nel grande dibattito sul verso libero. Dopo aver messo in musica poesie di Cros, Hugo, Lorrain e molti altri, la Krysinska si è infatti trovata a dover difendere l'originalità - e l'anteriorità - delle sue scelte di versificazione dalle accuse di plagio di Gustave Kahn. Questa polemica, che l'ha vista "vilipendée par bon nombre de ses contemporains», ha impedito secondo Whidden una lettura obiettiva delle sue opere che, reagendo alle indicazioni del Parnasse, mostrano, oltre all'introduzione del verso libero, «une attention aiguë portée à la matérialité sonore du langage dans la poésie» e un asse tematico molto innovativo per l'epoca: «le rôle et l'expression de la femme dans l'histoire». 